University of Nebraska - Lincoln

DigitalCommons@University of Nebraska - Lincoln

USDA National Wildlife Research Center - Staff Publications
U.S. Department of Agriculture: Animal and Plant Health Inspection Service

2011

\title{
Acute Toxicity, Histopathology, and Coagulopathy in American Kestrels (Falco sparverius) Following Administration of the Rodenticide Diphacinone
}

\author{
Barnett A. Rattner \\ Patuxent Wildlife Research Center, brattner@usgs.gov \\ Katherine E. Horak \\ USDA/APHIS/WS National Wildlife Research Center, katherine.e.horak@aphis.usda.gov \\ Sarah E. Warner \\ Patuxent Wildlife Research Center, sarah_warner@fws.gov \\ Daniel D. Day \\ Patuxent Wildlife Research Center \\ Carol U. Meteyer \\ U.S. Geological Survey, cmeteyer@usgs.gov
}

See next page for additional authors

Follow this and additional works at: https://digitalcommons.unl.edu/icwdm_usdanwrc

Part of the Life Sciences Commons

Rattner, Barnett A.; Horak, Katherine E.; Warner, Sarah E.; Day, Daniel D.; Meteyer, Carol U.; Volker, Steven F.; Eisemann, John D.; and Johnston, John J., "Acute Toxicity, Histopathology, and Coagulopathy in American Kestrels (Falco sparverius) Following Administration of the Rodenticide Diphacinone" (2011). USDA National Wildlife Research Center - Staff Publications. 1330.

https://digitalcommons.unl.edu/icwdm_usdanwrc/1330

This Article is brought to you for free and open access by the U.S. Department of Agriculture: Animal and Plant Health Inspection Service at DigitalCommons@University of Nebraska - Lincoln. It has been accepted for inclusion in USDA National Wildlife Research Center - Staff Publications by an authorized administrator of DigitalCommons@University of Nebraska - Lincoln. 


\section{Authors}

Barnett A. Rattner, Katherine E. Horak, Sarah E. Warner, Daniel D. Day, Carol U. Meteyer, Steven F. Volker, John D. Eisemann, and John J. Johnston 


\title{
ACUTE TOXICITY, HISTOPATHOLOGY, AND COAGULOPATHY IN AMERICAN KESTRELS (FALCO SPARVERIUS) FOLLOWING ADMINISTRATION OF THE RODENTICIDE DIPHACINONE
}

\author{
Barnett A. Rattner, ${ }^{*} \nmid$ Katherine E. Horak $₫$ Sarah E. Warner, $†$ Daniel D. Day $\nmid$ Carol U. Meteyer, $§$ \\ SteVen F. VolKer, $\ddagger$ John D. Eisemann, $\ddagger$ and John J. Johnston $\|$ \\ $\dagger$ Patuxent Wildlife Research Center, U.S. Geological Survey, Beltsville, Maryland \\ $\ddagger$ National Wildlife Research Center, U.S. Department of Agriculture, Fort Collins, Colorado \\ $\S$ National Wildlife Health Center, U.S. Geological Survey, Madison, Wisconsin \\ \|U.S. Department of Agriculture, Food Safety and Inspection Service, Fort Collins, Colorado
}

(Submitted 14 November 2010; Returned for Revision 3 January 2011; Accepted 11 January 2011)

\begin{abstract}
The acute oral toxicity of the anticoagulant rodenticide diphacinone was found to be over 20 times greater in American kestrels (Falco sparverius; median lethal dose $96.8 \mathrm{mg} / \mathrm{kg}$ body weight) compared with Northern bobwhite (Colinus virginianus) and mallards (Anas platyrhynchos). Modest evidence of internal bleeding was observed at necropsy, although histological examination of heart, liver, kidney, lung, intestine, and skeletal muscle revealed hemorrhage over a wide range of doses $(35.1-675 \mathrm{mg} / \mathrm{kg})$. Residue analysis suggests that the half-life of diphacinone in the liver of kestrels that survived was relatively short, with the majority of the dose cleared within $7 \mathrm{~d}$ of exposure. Several precise and sensitive clotting assays (prothrombin time, Russell's viper venom time, thrombin clotting time) were adapted for use in this species, and oral administration of diphacinone at $50 \mathrm{mg} / \mathrm{kg}$ increased prothrombin time and Russell's viper venom time at 48 and $96 \mathrm{~h}$ postdose compared with controls. Prolongation of in vitro clotting time reflects impaired coagulation complex activity, and generally corresponded with the onset of overt signs of toxicity and lethality. In view of the toxicity and risk evaluation data derived from American kestrels, the involvement of diphacinone in some raptor mortality events, and the paucity of threshold effects data following short-term dietary exposure for birds of prey, additional feeding trials with captive raptors are warranted to characterize more fully the risk of secondary poisoning. Environ. Toxicol. Chem. 2011;30:1213-1222. (C) 2011 SETAC
\end{abstract}

Keywords-Anticoagulant rodenticides Birds Clotting time Diphacinone Secondary poisoning

\section{INTRODUCTION}

Several anticoagulant rodenticides have been identified as hazards to predatory and scavenging birds on a worldwide scale. Various targeted surveillance programs have reported high detection rates of anticoagulant rodenticide residues in liver of birds of prey collected in New York (49\% of 265 raptors, 1998-2001) [1], France (73\% of 30 raptors, 2003) [2], Great Britain (37\% of 351 owls and kestrels, 2003-2005; derived from Walker et al. [3]), and western Canada (70\% of 164 owls, 1988-2003) [4]. Although diagnostic residue concentrations associated with adverse effects in raptors have yet to be clearly established, the cause of death was attributed to secondary rodenticide poisoning in up to $14.6 \%$ of the exposure incidents $[1,3,4]$.

Monitoring avian species during large-scale rodent eradication operations revealed that several second-generation rodenticides can result in nontarget mortality and even populationlevel effects through direct ingestion of bait or consumption of poisoned rodents. For example, baiting operations using brodifacoum resulted in $>80 \%$ reductions in woodhen (Gallirallus australis) populations and loss of some raptors (e.g., Australasian harrier, Circus approximans; morepork, Ninox novaesee-

All Supplemental Data may be found in the online version of this article.

Portions of this manuscript were presented at the 24th Vertebrate Pest Conference, February 22-25, 2010, Sacramento, California, USA.

* To whom correspondence may be addressed (brattner@usgs.gov).

Published online 18 February 2011 in Wiley Online Library (wileyonlinelibrary.com). landiae) at Stewart, Ulva, and Inner Chetwode Islands in New Zealand [5,6]; the death of 13 ravens (Corvus corax) at Langara Island in British Columbia, Canada [7]; and, most recently, the apparent poisoning of 320 glaucous-winged gulls (Larus glaucescens) and 46 bald eagles (Haliaeetus leucocephalus) on Rat Island, Alaska (http://alaska.fws.gov/ratislandreviewfinal.pdf). Such rodent eradication operations use formulations and application rates that are atypical of more routine use of second-generation rodenticides. Nonetheless, the global magnitude of nontarget poisoning of wildlife both in pest eradication programs and in the more routine use of rodenticides is unknown, and most events probably go unnoticed or are not reported.

A risk assessment conducted by the U.S. Environmental Protection Agency (U.S. EPA) in 2002 identified several rodenticides that pose significant risk to birds and nontarget mammals, in part because of their toxicity and prolonged retention in liver [8]. Restrictions on the sale, distribution, and packaging of brodifacoum, difethialone, bromadiolone, and difenacoum were subsequently instituted by the U.S. EPA in 2008 (http://www.epa.gov/pesticides/reregistration/ rodenticides/finalriskdecision.htm). This action will likely be offset by expanded use of acute toxicants and other anticoagulant rodenticides, including diphacinone (http://www.regulations.gov/\#!documentDetail;D = EPA-HQ-OPP-2006-09550003). The hazard of diphacinone to nontarget organisms is inadequately characterized, although significant exposure and mortality suspected to be related to diphacinone have been reported for raptors (snowy owl, Nyctea scandiaca; redtailed hawk, Buteo jamaicensis; and Cooper's hawk, Accipiter 
cooperii) [1,9]. Here, we report overt signs of intoxication, histopathological responses, blood clotting time, residues, and lethality following diphacinone administration to American kestrels (Falco sparverius), a well-studied toxicological model species for raptors [10]. These data, in combination with similar measurements in Northern bobwhite (Colinus virginianus), will assist in the development of a pharmacodynamic model and a more complete risk assessment of diphacinone for birds.

\section{MATERIALS AND METHODS}

\section{Animals}

All animal procedures were approved by the Institutional Animal Care and Use Committee of the Patuxent Wildlife Research Center. American kestrels, propagated at the captive colony at Patuxent [11], were reared in vinyl-coated wire outdoor flight pens $(6.1 \mathrm{~m}$ long $\times 2.4 \mathrm{~m}$ wide $\times 2.1 \mathrm{~m}$ high $)$ containing a nest box, several perches, feed tray and a bowl of fresh water. Birds were maintained on daily rations of either Classic Bird of Prey diet (Nebraska Brand) supplemented with Vionate ${ }^{\circledR}$ (Gimborn US), dead mice (Mus musculus), or dead chicken (Gallus gallus) hatchlings. For toxicity tests, kestrels were moved from flight pens to small outdoor cages $(1.2 \mathrm{~m}$ long $\times 0.8 \mathrm{~m}$ wide $\times 0.6 \mathrm{~m}$ high) with a shade roof, rope perch, food tray and water bowl, where they were housed individually.

\section{Acute toxicity of diphacinone}

In range-finding trials, serious problems were encountered because of regurgitation of diphacinone (2-[diphenylacetyl]indan-1,3-dione; CAS 82-66-6; 99.2\% purity; Hacco) when administered as a suspension in vegetable oil or as a neat dose in a size-0 gelatin capsule (Eli Lilly). Through an iterative process, a method was developed that minimized regurgitation through repeated administration of small quantities of diphacinone (1-39 mg) as a divided dose over a 24-h period. Briefly, kestrels (body weight 98-127 g) were transferred from flight pens to small cages, acclimated for two weeks, fed Classic Bird of Prey diet, and weighed on the afternoon (1600-1700h) before dosing. Individual size-4 gelatin capsules were weighed on a top-loading balance (1 mg sensitivity). Neat diphacinone was added to the capsule, which was then reweighed to verify dose. Freeze-dried diet and $5 \mu$ l FD\&C Blue No. 1 food dye (marker for regurgitation; McCormick) were then added to the capsule. After an overnight fast with water accessible at all times, the capsule was administered to the level of the proventriculus using a modified pilling device (pet piller; Jorgensen Laboratories) and a plastic probe that were both $8 \mathrm{~mm}$ in diameter. The capsule was chased with $0.2 \mathrm{ml}$ distilled water delivered with a 16-gauge curved ball-point feeding needle (Popper \& Sons). The dosed kestrel was returned to its pen and immediately presented with a highly desired food item (dead chicken hatchling). This dosing procedure was repeated up to three additional times within a 24 -h period (i.e., at $\sim 0900,1300$, 1700 , and $0800 \mathrm{~h}$ ), with the total daily dose ranging from 35.1 to $675 \mathrm{mg} / \mathrm{kg}$. In total, 19 kestrels (two-year-old adults randomly assigned to dose, sexes divided nearly equally among doses) received diphacinone. Four kestrels that served as controls were similarly treated, except that capsules did not contain diphacinone. This acute toxicity study was conducted between September 14 and October 7, 2009, using a sequential dosing scheme that attempted to minimize the number of test subjects. Ambient temperature ranged from 9 to $29^{\circ} \mathrm{C}$, which is typical for Maryland, USA, at that time of year. Pens were lined with Kraft paper to monitor regurgitation, and birds were observed daily for overt signs of intoxication several times during daylight for one week. Birds that succumbed during the trial and survivors (euthanized with carbon dioxide) were necropsied. Portions of heart, liver, kidney, lung, spleen, intestine, brain, skeletal muscle, and occasionally other tissues were fixed in phosphate-buffered formalin for histopathological analysis, and the liver was frozen at $-20^{\circ} \mathrm{C}$ for residue analysis.

\section{Histopathology}

In the acute toxicity study, formalin-fixed tissues were processed (American HistoLabs) using standard procedures [12]. In general, four 4- $\mu \mathrm{m}$ sections per tissue, in steps of $100 \mu \mathrm{m}$, were mounted on slides and stained with hematoxylin and eosin. All sections were consistently examined at a magnification of $\times 200$, and, if abnormalities were observed (e.g., hemorrhage and other lesions), the tissue was re-examined at a magnification of $\times 400$.

\section{Diphacinone purity and liver residue analysis}

Neat diphacinone ( $5 \mathrm{mg}$ ) was dissolved in a volumetric flask with ethyl acetate to a nominal concentration of $1 \mathrm{mg} / \mathrm{ml}$ and diluted with a methanol solution containing $5 \mathrm{mM}$ tetrabutylammonium dihydrogen phosphate (TBAP) to a nominal concentration of $50 \mu \mathrm{g} / \mathrm{ml}$. Samples were analyzed on a C18 column $(\mathrm{ODS} / \mathrm{H}, 4.6 \times 250 \mathrm{~mm}, 5 \mu \mathrm{m}$ column; Keystone Scientific) by reversed phase ion-paired high-performance liquid (RP-HPLC) chromatography (Agilent 1100 series; Agilent Technologies). The mobile phase was $5 \mathrm{mM}$ TBAP in a $\mathrm{pH}$ 7.5 solution of 20:80 water:methanol. Standards and samples were chromatographed at $1 \mathrm{ml} / \mathrm{min}$ for $10 \mathrm{~min}$ and detected at $285 \mathrm{~nm}$. The determined purity for five replicate samples averaged $99.2 \%$ with precision (percentage relative standard deviation [SD], coefficient of variation $[\mathrm{CV}]$ ) of $0.60 \%$.

Kestrel livers were homogenized using liquid nitrogen with a mortar and pestle, and duplicate samples from each homogenate were weighed into digestion vessels. Chlorophacinone was added to each sample to serve as a surrogate standard. Acetonitrile was added to each sample, and samples were extracted at $125^{\circ} \mathrm{C}$ for $60 \mathrm{~min}$ using a microwave-accelerated reaction system (CEM Corporation). Extracts were then decanted into glass tubes and reduced to dryness, and residues were reconstituted in chloroform by vortex mixing and sonication. Hexanes were added to the samples, which were again vortexed and sonicated. Sample extracts were then filtered $(0.7 \mu \mathrm{m}$ glass fiber syringe filters; Whatman), cleaned by loading filtrates onto conditioned (chloroform:hexanes, 2:1) $500 \mathrm{mg} / 3 \mathrm{ml}$ Strata-X-AW solidphase extraction cartridges (Phenomenex), and eluted with methanolic solution containing $15 \mathrm{mM}$ TBAP. Each eluate was reduced to dryness, reconstituted in mobile phase $(50 \%$ $5 \mathrm{mM}$ TBAP in $\mathrm{pH} 8.56 \mathrm{mM}$ phosphate buffer $/ 50 \%$ methanol), and filtered into vials for RP-HPLC analysis. Diphacinone concentrations were determined using an Agilent 1100 series HPLC system and Gemini C18, $3.0 \times 150 \mathrm{~mm}$, 3- $\mu \mathrm{m}$ column (Phenomenex). The aqueous mobile phase was $5 \mathrm{mM}$ TBAP in $\mathrm{pH} 8.56 \mathrm{mM}$ potassium phosphate, and the organic mobile phase was $5 \mathrm{mM}$ TBAP in methanol. For each $30-\mu$ injection, the methanolic component was maintained at $55 \%$ for $7 \mathrm{~min}$, followed by a linear gradient to $77.5 \%$ over $10 \mathrm{~min}$, raised to $85 \%$ over the next $10 \mathrm{~min}$, and returned to the starting composition for $7.5 \mathrm{~min}$. Diphacinone and surrogate were detected at $325 \mathrm{~nm}$. 
Control quail liver samples spiked with diphacinone at nominal concentrations of $0.2 \mu \mathrm{g} / \mathrm{g}$ and $2 \mu \mathrm{g} / \mathrm{g}$ produced surrogate-corrected recoveries $\pm \mathrm{SD}$ of $144 \pm 14 \% \quad(n=6)$ and $109 \pm 7 \%(n=6)$, respectively. Chlorophacinone was spiked at a nominal concentration of $3.8 \mu \mathrm{g} / \mathrm{g}$ and used as the surrogate to correct diphacinone recoveries. Surrogate recoveries were $91 \pm 4 \%$ and $87 \pm 2 \%$, respectively, at the two diphacinone spiking levels. No significant interference was observed at the retention time for either diphacinone $(\sim 19.5 \mathrm{~min})$ or chlorophacinone ( $\sim 23 \mathrm{~min})$ in extracted quail livers. The method limit of detection (three times the signal:noise ratio) and method limit of quantitation (10 times the signal:noise ratio) were $0.095 \mu \mathrm{g} / \mathrm{g}$ and $0.317 \mu \mathrm{g} / \mathrm{g}$, respectively. The precision for duplicate determinations in liver samples $(n=19$ dosed kestrels) averaged $20 \%$.

\section{Effects of diphacinone on clotting time}

As part of a study to develop a physiologically based pharmacokinetic model, kestrels (94-137 g, 1- to 3-year-old adults) received diphacinone as a single sublethal dose using procedures employed in the acute toxicity trial. Between October 18 and November 2, 2009 (ambient temperature $2-25^{\circ} \mathrm{C}$ ), treated birds received $50 \mathrm{mg} / \mathrm{kg}$ body weight, and blood was drawn at $6,24,48,96$, and $168 \mathrm{~h}$ after dosing $(n=2$ males and 2 females per sampling time). Controls $(n=2$ males and 2 females) received capsules containing only freeze-dried diet and dye, and blood was collected after $168 \mathrm{~h}$. Blood collection entailed drawing a $0.9-\mathrm{ml}$ jugular venipuncture sample into a 1$\mathrm{ml}$ syringe containing $0.1 \mathrm{ml}$ of $3.2 \%$ sodium citrate (SigmaAldrich). Blood samples were centrifuged (2,000 $\mathrm{g}$ for $5 \mathrm{~min}$ ), and an aliquot of the citrated plasma $(\sim 250 \mu \mathrm{l})$ was frozen and stored at $-80^{\circ} \mathrm{C}$ for clotting assays. A combination of assays (prothrombin time and Russell's viper venom (RVV) time to determine vitamin K-dependent coagulopathies, fibrinogen concentration to rule out nonspecific influences on clotting time) [13] was used to analyze kestrel samples. Body-weight change over the course of the trial and liver:body weight ratio at sacrifice were also determined in this study.

\section{Prothrombin time}

In this assay, excess tissue factor and phospholipid (thromboplastin) interact with plasma factor VII to form an active complex, and through a cascade of reactions fibrinogen is converted to fibrin [13]. Prothrombin time (PT) was determined using a BBL fibrometer (Becton Dickinson). Instrument performance over one year was assessed using human reference samples and Simplastin ${ }^{\circledR}$ (rabbit brain thromboplastin; Trinity Biotech); PT values were within the reference range provided by the supplier (mean $\pm \mathrm{SD}$ of sample level 1: $16.6 \pm 0.5 \mathrm{~s}$, $n=8$ assays; sample level 2: $35.5 \pm 1.67 \mathrm{~s}, n=7$ assays), and interassay precision $(2.1 \%$ and $3.9 \%$, respectively) was satisfactory.

Because mammalian thromboplastin does not promote rapid clot formation in avian species, crude chick hatchling thromboplastin (CHT) was prepared [13-15]. For the assay of citrated kestrel plasma samples, a 50-mg aliquot of $\mathrm{CHT}$ was suspended in $2,500 \mu \mathrm{l}$ of $25 \mathrm{mM} \mathrm{CaCl}_{2}$ and incubated at $42^{\circ} \mathrm{C}$ for $15 \mathrm{~min}$ with intermittent vortexing. The suspension was centrifuged $(1,500 \mathrm{~g}$ for $20 \mathrm{~min})$, and the supernatant was diluted $1: 1$ with $25 \mathrm{mM} \mathrm{CaCl}_{2}(\sim 220 \mu \mathrm{g}$ protein/ml $)$. Kestrel plasma $(100 \mu \mathrm{l})$ was incubated at $37^{\circ} \mathrm{C}$ for $2 \mathrm{~min}$ in a sample cup, and the clotting reaction was initiated by the addition of $200 \mu$ l diluted CHT. In preliminary studies, PT of citrated kestrel plasma was related to CHT dilution (Fig. 1), and PT of kestrel plasma

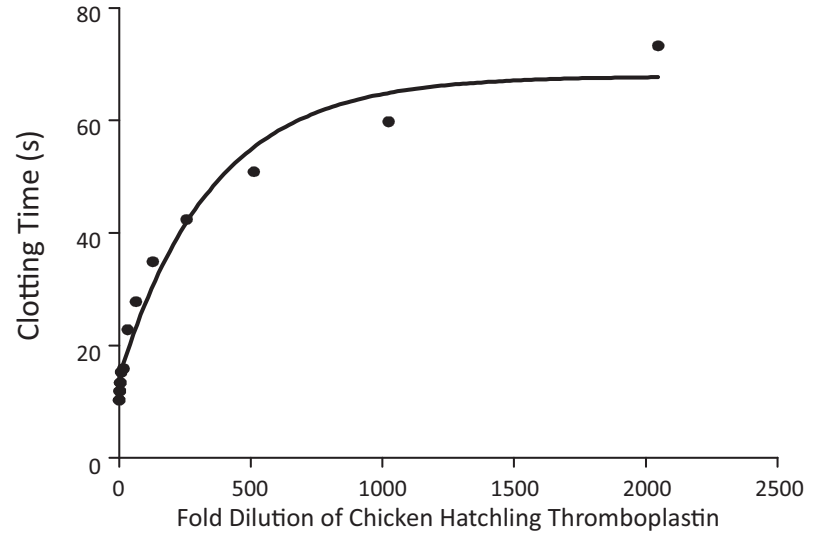

Fig. 1. Clot-promoting potential (prothrombin time) of undiluted and diluted $(1: 2$ to $1: 2,048)$ chicken hatchling thromboplastin incubated with citrated

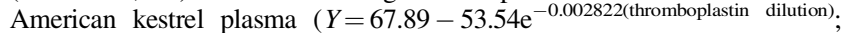
$\left.R^{2}=0.97\right)$

diluted with $8.3 \mathrm{mM} \mathrm{Na} / \mathrm{K}$ phosphate buffer ( $\mathrm{pH} 7.2$ ) was relatively stable in reactions containing as little as $50 \%$ plasma (Supplemental Data, Fig. S1). In these preliminary studies, intraassay precision for duplicate determinations of kestrel plasma was $2.0 \pm 2.2 \%(n=11)$, but limited sample volume permitted only a single determination in diphacinone-treated kestrels.

\section{Russell's viper venom time}

Russell's viper venom activates factor $\mathrm{X}$ in the common pathway of the clotting cascade [13]. Reconstituted RVV factor $\mathrm{X}$ activator (American Diagnostica) was diluted 1:10 with imidazole-buffered saline (IBS; $0.0125 \mathrm{M}$ imidazole $0.109 \mathrm{M}$ $\mathrm{NaCl}, \mathrm{pH} 7.4$; Sigma-Aldrich) and maintained at room temperature. Kestrel plasma $(100 \mu \mathrm{l})$ was incubated at $37^{\circ} \mathrm{C}$ for $2 \mathrm{~min}$, and $100 \mu \mathrm{l}$ of diluted RVV was added and incubated for $15 \mathrm{~s}$. The reaction was initiated with $100 \mu \mathrm{l} 25 \mathrm{mM} \mathrm{CaCl}_{2}$, and RVV time (RVVT) was determined [16]. In preliminary studies, RVVT remained relatively stable when kestrel plasma was diluted by as much as $60 \%$ with phosphate buffer (Fig. 2), and intraassay precision for duplicate determinations was $3.4 \pm 4.1 \%(n=9)$. Because of limited volume, some plasma samples from diphacinone-treated kestrels were diluted in

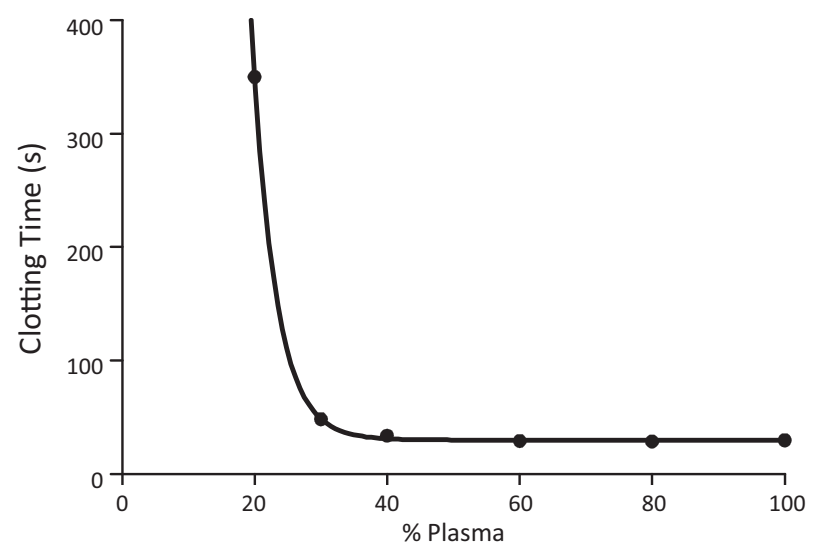

Fig. 2. Effect of diluting citrated kestrel plasma with phosphate buffer (100, $80,60,50,40,30$, and $20 \%$ plasma) on Russell's viper venom clotting time $\left(Y=30.11+94634 \mathrm{e}^{-0.2845(\% \text { plasma })} ; R^{2}=0.99\right)$. 
phosphate buffer, and RVVT was adjusted using the dilution curve.

\section{Thrombin clotting time}

This assay determines the time taken for fibrinogen to be converted to fibrin [16]. The thrombin clotting time assay is an indicator of fibrinogen concentration in a plasma sample, which is insensitive to deficiency of vitamin K-dependent clotting factors. Fibrinogen deficiency resulting from pathophysiologic conditions or improper sample collection can prolong clotting time, and in rodenticide toxicity studies it is important to verify that fibrinogen concentration is adequate to promote clot formation. Assay reagents included bovine thrombin and human fibrinogen reference material (AMAX Fibrinogen Kit; Trinity Biotech). A fibrinogen standard curve was prepared (65$520 \mathrm{mg} / \mathrm{dl}$ ), and kestrel plasma samples were thawed a second time and diluted 1:10 with IBS. Diluted plasma $(200 \mu$ l total volume) was incubated at $37^{\circ} \mathrm{C}$ for $2 \mathrm{~min}$, and the reaction was initiated by the addition of $100 \mu$ l of thrombin reagent. Clotting time of each sample was transformed to fibrinogen concentration $(\mathrm{mg} / \mathrm{dl})$ from the standard curve. In preliminary studies, intraassay precision for duplicate determinations of kestrel plasma was $1.8 \pm 2.2 \%(n=9)$.

\section{Statistical analysis}

For the acute toxicity trial, the relation between dose and survival and the median lethal dose (LD50) of diphacinone in kestrels was estimated using probit analysis (SAS Institute). A one-phase exponential decay model (Prism; GraphPad Software) was used to describe the relation between clotting time (PT and RVVT) and dilution of kestrel plasma. To examine the effects of a sublethal dose of diphacinone, body weight change, liver:body weight ratio, PT, RVVT, and thrombin clotting time were tested for homogeneity of variances $\left(F_{\max }\right.$ test) and normality (Shapiro-Wilk test, normal probability plot and descriptive statistics). The measurement endpoints were tested by one-way analysis of variance (ANOVA), and clotting times of diphacinone-treated kestrels (hours postdose) were compared with the control group using Dunnett's test.

\section{RESULTS}

\section{Acute toxicity of diphacinone}

At necropsy, birds were in good body condition with no evidence of starvation or dehydration. At the highest dosage levels, birds received three capsules containing diphacinone but succumbed before receiving the fourth (and final) capsule of their divided dose, so the actual administered doses were 675 , 450 , and $300 \mathrm{mg} / \mathrm{kg}$ (Table 1). These individuals appeared subdued, died within 8 to $23 \mathrm{~h}$ of receiving the initial capsule of the divided dose, and at necropsy exhibited some macroscopic evidence of hemorrhage, but not frank bleeding. There was no history or evidence of trauma in any of the diphacinonetreated or control birds. Histological examination of tissues revealed microscopic hemorrhage in the heart, liver, kidney, lung, intestine, and skeletal muscle of some individuals (Fig. 3). At the intermediate doses ( 266.7 down to $118.6 \mathrm{mg} / \mathrm{kg}$ ), all birds died within 8 to $47 \mathrm{~h}$, with the exception of a single bird that exhibited signs of intoxication but then recovered. Gross necropsy revealed some evidence of hemorrhage in the gastrointestinal tract, and the liver was often mottled. Microscopically, perivascular hemorrhage in the lung and free blood in the lamia propria of the intestine were consistently found. At $79.0 \mathrm{mg} / \mathrm{kg}$, one of three kestrels died after $27 \mathrm{~h}$. At the lowest doses (52.7 and $35.1 \mathrm{mg} / \mathrm{kg}$ ), all birds survived but exhibited varying degrees of hemorrhage in liver, lung, lamina propria of the intestine, and spleen. Kestrels that succumbed often exhibited a progression of toxic signs, including losing balance on their perch, standing on the floor of the pen rather than on their perch, being nonreactive when approached, showing subdued behavior, and showing tan urate deposits. All controls survived the 7-d trial and did not exhibit gross or microscopic evidence of hemorrhage other than in the airways (commonly found in birds euthanized with carbon dioxide). Probit analysis indicated that survival of kestrels during the 7-d acute toxicity trial was significantly $(p<0.023)$ related to the total administered dose of diphacinone. The LD50 of diphacinone for kestrels was estimated to be $96.8 \mathrm{mg} / \mathrm{kg}$ (95\% confidence interval 37.9 $219 \mathrm{mg} / \mathrm{kg}$ ), and the slope of the dose-response curve was $6.69 \pm 2.94$ probit/ $/ \log _{10}$.

Kestrels that died within 8 to $23 \mathrm{~h}$ received the largest doses of diphacinone and had greater concentrations of diphacinone in liver $(32.8-56.3 \mu \mathrm{g} / \mathrm{g}$ wet wt) than birds that died 27 to $47 \mathrm{~h}$ postdose (13.4-19.4 $\mu \mathrm{g} / \mathrm{g}$ wet wt; Table 1 and Fig. 4). Diphacinone appeared to be cleared rapidly from the liver, insofar as kestrels that survived the 7-d trial generally had concentrations $<1 \mu \mathrm{g} / \mathrm{g}$.

\section{Sublethal exposure and effects on clotting time}

All birds receiving a single oral dose of $50 \mathrm{mg}$ diphacinone/ $\mathrm{kg}$ (estimated LD10 to LD15) survived to their scheduled time of sacrifice. No overt signs of toxicity were observed, and body weight change and liver:body weight ratio were not affected by diphacinone $(p>0.10)$. Two of the twenty-four blood samples were problematic and were excluded. One of these samples had no detectable fibrinogen, and the other sample was poorly drawn. Fibrinogen concentration in the remaining 22 samples was between 41.3 and $160.2 \mathrm{mg} / \mathrm{dl}$ and did not differ among sampling times $(p>0.20)$. Compared with that in the control group, PT at both 48 and $96 \mathrm{~h}$ postdose was significantly prolonged (2.5-fold and 1.6-fold, respectively; $p<0.05$, logtransformed data), but by $168 \mathrm{~h}$ PT had returned to control levels (Fig. 5). A similar but more pronounced trend was observed for RVVT, with clotting time prolonged at 48 and $96 \mathrm{~h}$ (7.6-fold and 3.3-fold, respectively; $p<0.05$, log-transformed data; Fig. 6). Notably, one RVVT value at $24 \mathrm{~h}$ postdose (173.9s) was 4.8-fold greater than mean RVVT of controls (mean $\pm \mathrm{SD}$, $34.2 \pm 4.87 \mathrm{~s}$ ), which is suggestive of coagulopathy.

\section{DISCUSSION}

\section{Lethality and overt toxicity}

With a relatively small number of individuals in a sequential acute oral dosing scheme, diphacinone was found to be moderately toxic (LD50 $96.8 \mathrm{mg} / \mathrm{kg}$ ) [17] to American kestrels. At doses that evoked lethality $(\geq 79 \mathrm{mg} / \mathrm{kg})$, birds exhibited ataxia and subdued behavior but no signs of external bleeding. Based on the median lethal dose, kestrels were found to be about 20 to 30 times more sensitive to diphacinone than Northern bobwhite (LD50 2,014 mg/kg) [13] and mallards (Anas platyrhynchos; LD50 $3,158 \mathrm{mg} / \mathrm{kg}$ ) [8].

Although diphacinone is linked to secondary poisoning [1,9], only a few controlled studies have examined its toxicity in raptors. In an investigation of golden eagles (Aquila chrysaetos) fed muscle from diphacinone-treated sheep (Ovis aries; muscle contained $2.7 \mathrm{mg}$ diphacinone $/ \mathrm{kg}$ ) for 5 to $10 \mathrm{~d}$, adverse effects were observed at much lower concentrations [18] than in kestrels. One eagle that received a cumulative dose of $1.38 \mathrm{mg} /$ 


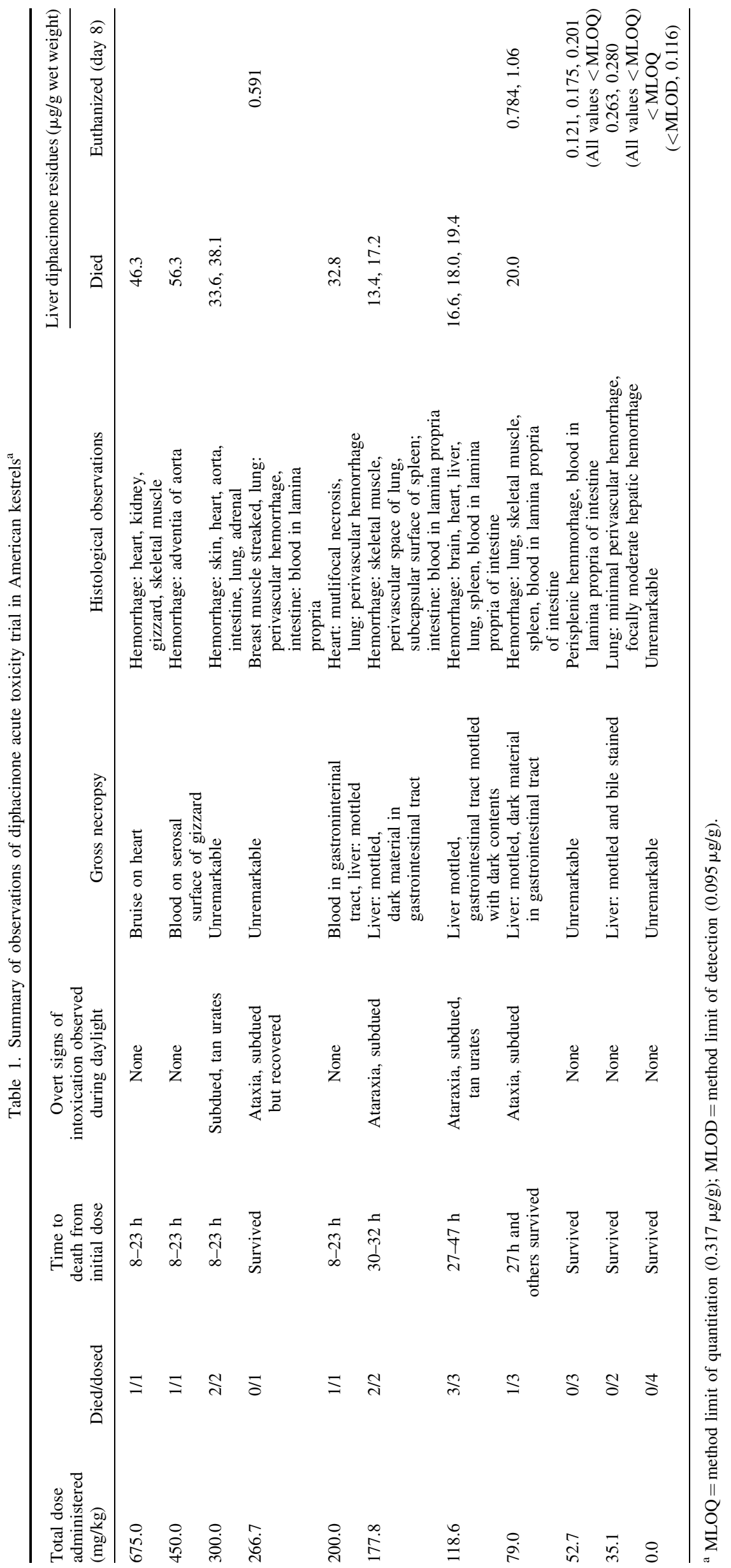




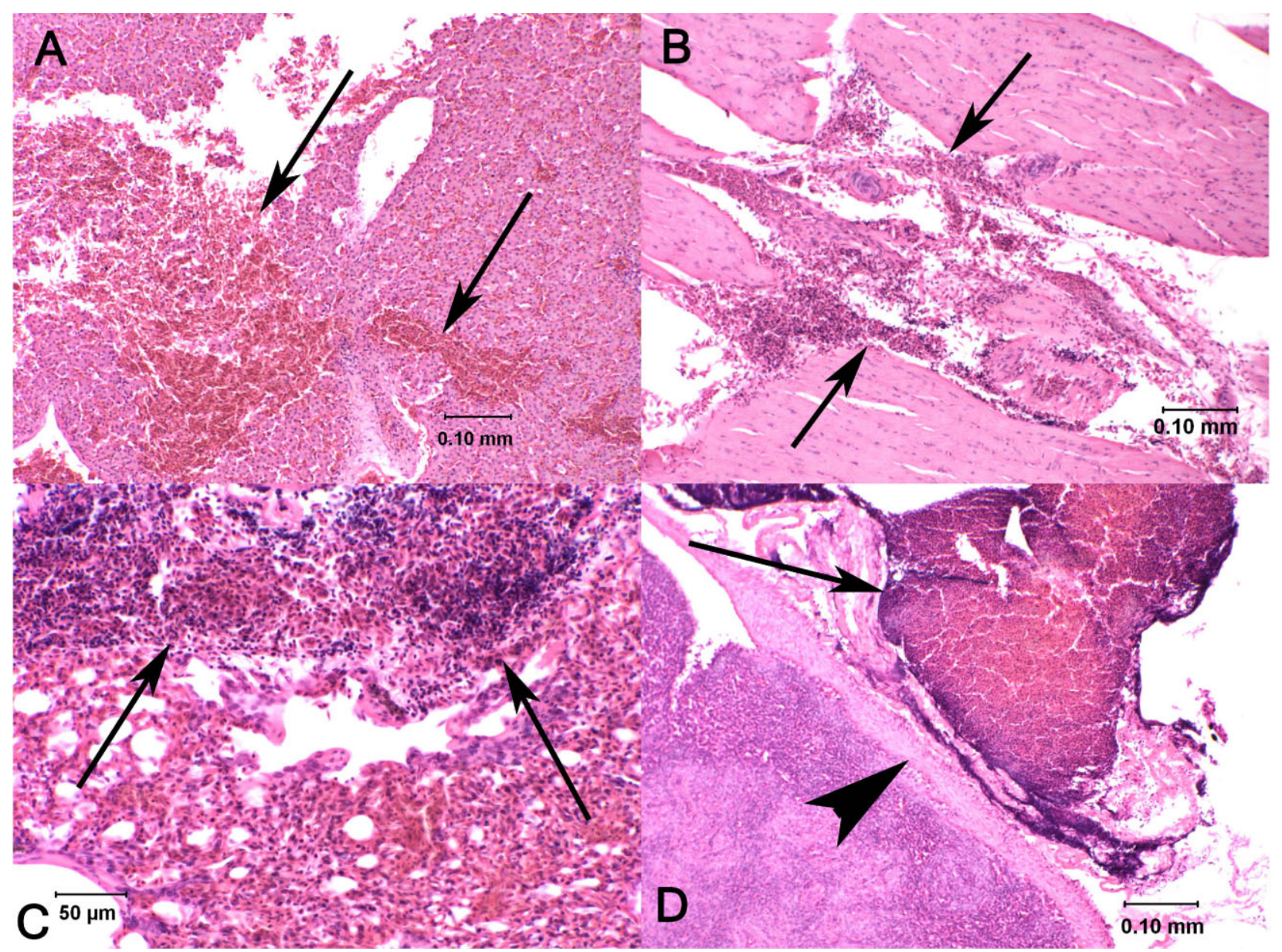

Fig. 3. Microscopic hematoxylin- and eosin-stained sections of tissues from four different kestrels experimentally dosed with diphacinone. (A) Liver with random foci of hemorrhage (arrows) associated with disruption of hepatic parenchyma (dose $300 \mathrm{mg} / \mathrm{kg}$ ). (B) Skeletal muscle with hemorrhage (arrows) dissecting between muscle fibers (dose $79.0 \mathrm{mg} / \mathrm{kg}$ ). (C) Lung hemorrhage (arrows) compressing airways (dose $118.6 \mathrm{mg} / \mathrm{kg}$ ). (D) Spleen with hemorrhage (arrow) evident outside of its capsule (arrowhead; dose $52.7 \mathrm{mg} / \mathrm{kg}$ ).

$\mathrm{kg}$ body weight exhibited extreme weakness, and another eagle that received a cumulative dose of $1.08 \mathrm{mg} / \mathrm{kg}$ exhibited hemorrhage from a wing and ataxia. However, all eagles survived the trial. In another study, great horned owls (Bubo virginianus) and a saw-whet owl (Aegolius acadicus) were fed diphacinonepoisoned mice (Peromyscus maniculatus; $0.01 \%$ diphacinone bait) for $5 \mathrm{~d}$, and barn owls (Tyto alba) were fed diphacinone-

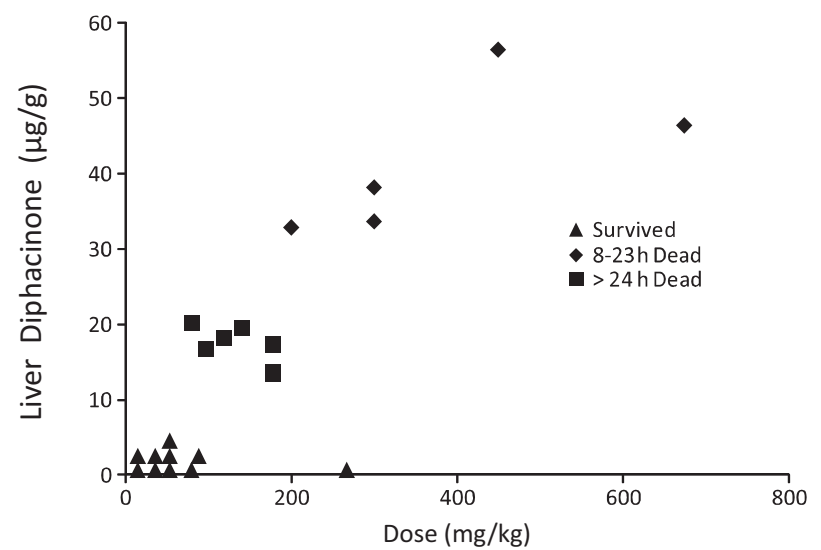

Fig. 4. Scatterplot depicting diphacinone dose and liver residues at time of death or when kestrels were euthanized. poisoned rats (Rattus norvegicus, $R$. rattus and $R$. exulans; $0.005 \%$ diphacinone bait) for $10 \mathrm{~d}$ [19]. Unfortunately, the quantity of diphacinone in the poisoned rodents was not analytically determined. A very rough estimate of the cumulative dose (ignoring absorption, metabolism, and elimination of diphacinone in the rodents) suggests that lethality and severe hemorrhage occurred in great horned owls that consumed mice that had eaten the equivalent of 3 to $4 \mathrm{mg}$ diphacinone $/ \mathrm{kg}$ of owl weight and a saw-whet owl that had consumed mice that had eaten the equivalent of about $55 \mathrm{mg}$ diphacinone $/ \mathrm{kg}$ of owl weight (V.M. Mendenhall, personal communication). No overt signs of toxicity were observed in barn owls that consumed rats that had eaten the equivalent of about 14 to $17 \mathrm{mg}$ diphacinone $/ \mathrm{kg}$ of owl weight. In another investigation, communally housed American crows (Corvus brachyrhynchos) were fed rats poisoned with $0.005 \%$ diphacinone for 1 or $6 \mathrm{~d}$ ( $n=10-11$ /group) [20]. Based solely on visual observations while determining time activity budgets, it was suggested that about $10 \mathrm{mg}$ of diphacinone was consumed following a single day of exposure, whereas $70 \mathrm{mg}$ of diphacinone was consumed by crows in the 6-d-exposure group. One of the crows exposed for $6 \mathrm{~d}$ exhibited blood in the nares and petechial hemorrhages on the cloacal mucosa. There was evidence of lengthened PT in both of the dosed groups compared with controls, but white blood cell counts and clinical plasma chemistries were unaffected. 


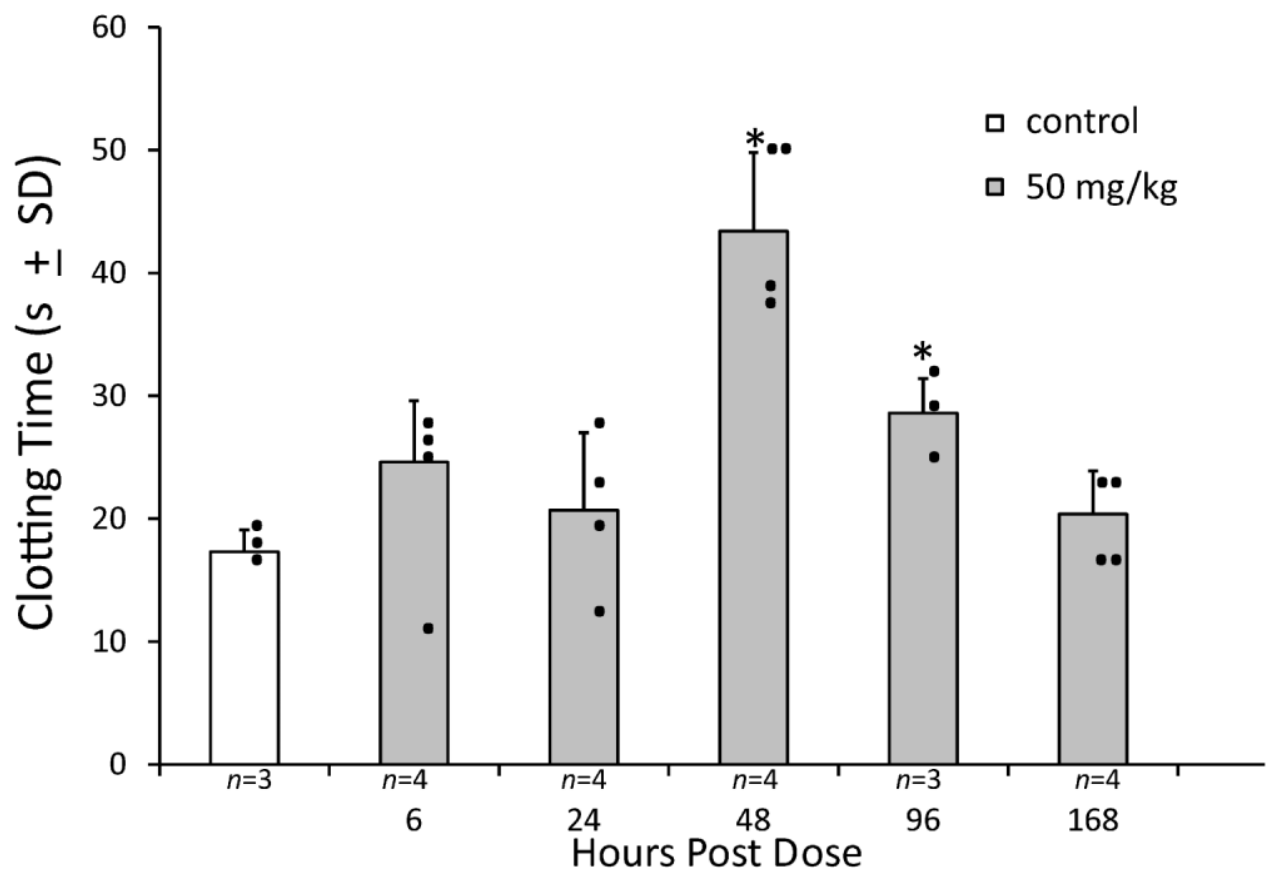

Fig. 5. Prothrombin time (individual values and mean \pm SD) of American kestrels dosed with diphacinone $(50 \mathrm{mg} / \mathrm{kg})$ at $6,24,48,96$, and $168 \mathrm{~h}$ postdose. $n=$ No. of kestrels. *Significantly different $(p<0.05)$ from control collected at $168 \mathrm{~h}$ postdose.

Taken together, these studies in raptors (Falconiformes, Strigiformes) indicate that they are considerably more sensitive to diphacinone than are bobwhite and mallards, and their protection may require more substantial safety margins than afforded by avian game bird species traditionally used in pesticide registration studies. Although many factors may account for differences in the sensitivity of raptors to anticoagulant rodenticides (e.g., vitamin K 2,3-epoxide reductase kinetics and inhibition, rodenticide metabolism and clearance), a recent study demonstrated that hydroxylation rates of warfarin in the great horned owl and snowy owl (Bubo scandiacus) are but a small fraction of that observed in mallards, chickens (Gallus gallus), and laboratory rats [21].

Histopathology, diphacinone residues, and clotting time

Only modest evidence of internal bleeding was apparent at necropsy in diphacinone-dosed kestrels. This is in contrast to findings of several anticoagulant rodenticide dosing trials in raptors that have reported external bleeding and extensive internal hemorrhages at necropsy $[18,19,22,23]$. Nonetheless,

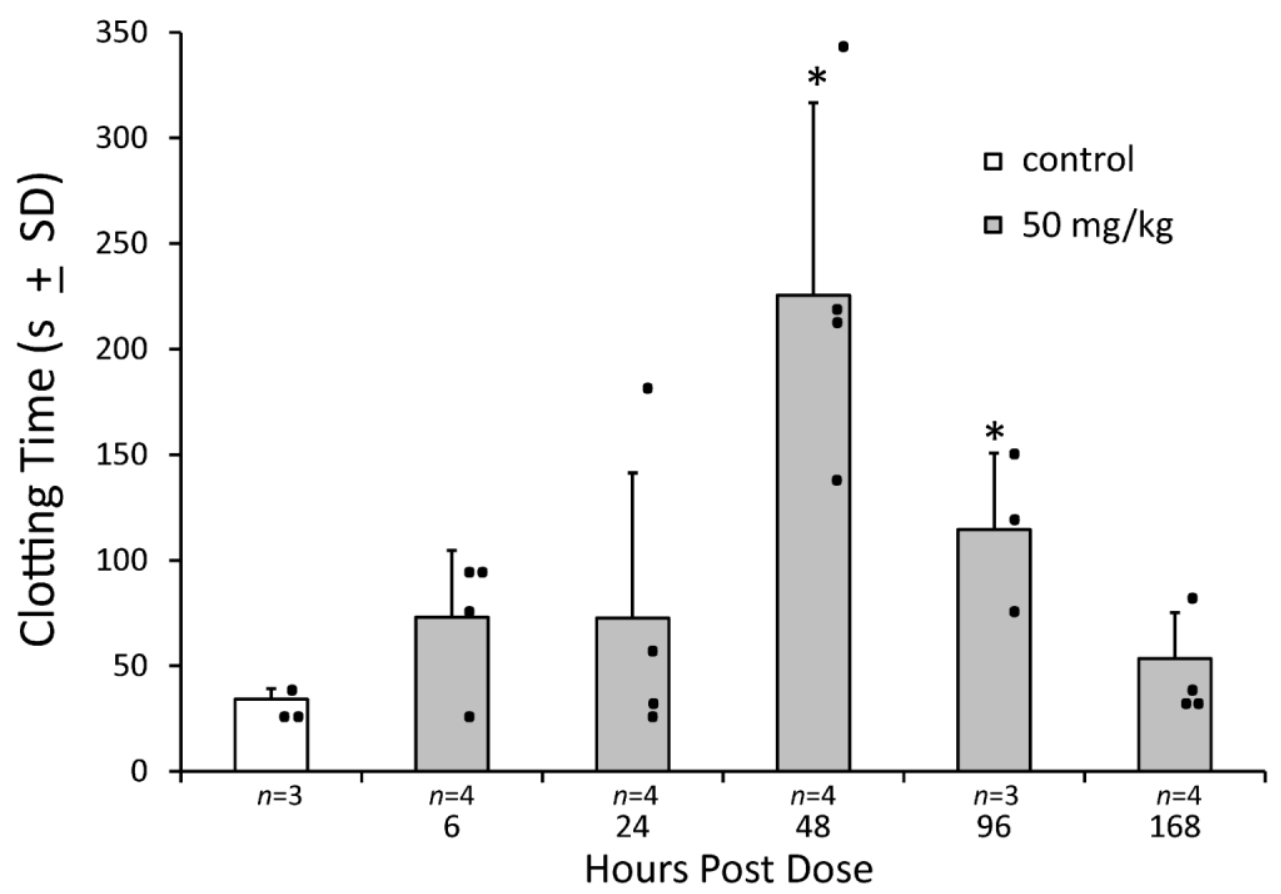

Fig. 6. Russell's viper venom time (individual values and mean \pm SD) of American kestrels dosed with diphacinone ( $50 \mathrm{mg} / \mathrm{kg}$ ) at $6,24,48,96$, and $168 \mathrm{~h}$ postdose . $n=$ No. of kestrels. * Significantly different $(p<0.05)$ from control. 
histopathological observations of kestrels document hemorrhage in heart, liver, kidney, lung, intestine, and skeletal muscle over a wide range of doses. Hemorrhage in major organs and vessels was likely to be a contributor to death, if not the definitive cause of mortality. However, histopathological observations alone are generally not considered diagnostic of anticoagulant intoxication [24].

Although the half-life of diphacinone in birds has yet to be reported, data from the present study indicate that it is rapidly cleared from liver, and presumably other tissues. For example, kestrels that succumbed to diphacinone (79 to $675 \mathrm{mg} / \mathrm{kg}$ ) within $48 \mathrm{~h}$ of dosing had liver concentrations exceeding $13 \mu \mathrm{g} / \mathrm{g}$ wet weight, whereas dosed individuals $(35.1-79 \mathrm{mg} /$ $\mathrm{kg}$, and a single bird at $266.7 \mathrm{mg} / \mathrm{kg}$ ) that survived the $7-\mathrm{d}$ trial had concentrations $<0.8 \mu \mathrm{g} / \mathrm{g}$. A preliminary estimate of the hepatic diphacinone half-life in kestrels orally dosed with $50 \mathrm{mg} / \mathrm{kg}$ suggests an overall half-life of $22 \mathrm{~h}$, with an initial phase (6-48 h postdose) half-life of $7.8 \mathrm{~h}$ and terminal phase (48-168 h postdose) half-life of $59.8 \mathrm{~h}$ (K.E. Horak, personal communication). The hepatic half-life of diphacinone in laboratory rats is about $3 \mathrm{~d}$ [25], and in pigs (Sus scrofa) the overall half-life is about $5.43 \mathrm{~d}$, with an initial phase (1-3 d) half-life of $1.30 \mathrm{~d}$ and a terminal phase half-life of $14.12 \mathrm{~d}$ [26]. Taken together, these data suggest that diphacinone is cleared more rapidly in kestrels than in rats and pigs. Tissue concentrations of anticoagulant rodenticides associated with adverse effects in raptors have yet to be definitively established, although hepatic concentrations of 0.1 to $0.2 \mu \mathrm{g}$ brodifacoum/g wet weight in combination with evidence of hemorrhage have been considered diagnostic of death from secondary rodenticide poisoning $[1,4]$. Notably, tissue concentrations of anticoagulant rodenticides are likely much greater in acute toxicity studies than in rodenticide-poisoned wild birds (N.B. Vyas, U.S. Geological Survey, Patuxent Wildlife Research Center, Beltsville, MD, personal communication), although histological evidence of hemorrhage in lung and liver of kestrels was apparent at 0.263 and $0.280 \mu \mathrm{g}$ diphacinone/g wet weight of liver, which is just above the diphacinone method limit of detection.

Anticoagulant rodenticides irreversibly inhibit vitamin $\mathrm{K}$ epoxide reductase that is necessary for post-translational carboxylation of the prothrombin group of serine protease coagulation factors (factors II, VII, IX, and X), and without the carboxyl group these factors do not assemble on cell surfaces to form active coagulation complexes [27]. Detection of vitamin $\mathrm{K}$-dependent coagulopathy in kestrels employed a combination of assays [13], namely, PT and RVVT, that reflect effects on clotting factors (for review see Powers [28]) and measurement of fibrinogen to rule out improper sample collection and other pathophysiologic conditions (e.g., hepatic synthetic failure, disseminated intravascular coagulation) that can affect clotting time [29]. Prolonged clotting time was apparent at $48 \mathrm{~h}$ following administration of a single oral $50 \mathrm{mg}$ diphacinone $/ \mathrm{kg}$ dose to kestrels, remained elevated at $96 \mathrm{~h}$ postdose, and clearly exceeded the $25 \%$ increase above reference PT values that is suggestive of anticoagulant exposure [30]. The lag time between dosing and development of coagulopathy reflects the half-life clearance of functional coagulation factors (halflife of factors II, VII, IX, and X in humans are 120, 6, 18, and $65 \mathrm{~h}$, respectively ([31]; see http://www.r2diagnostics.com/ cascade_r2/r2.cascade2007.pdf) and increasing circulation of des-carboxy dysfunctional factors. Notably, the onset of prolonged PT and RVVT corresponds with, and may even precede, overt toxicity and lethality at the doses used in the acute toxicity studies. A similar time course of coagulopathy was observed in a small trial in which kestrels received $50 \mathrm{mg} / \mathrm{kg}$ as a divided dose (four capsules administered over a 24-h period) [32]. In the study of golden eagles fed meat from diphacinone-treated sheep [18], overt signs of toxicity appeared to correspond to prolonged PT, and several other studies in various species of birds have documented prolonged clotting within days of gavage or dietary exposure to anticoagulant rodenticides [33-36] (K.H. Webster, 2009, Master's thesis, Simon Fraser University, Burnaby, BC, Canada).

\section{Risk evaluation}

As part of a Special Local Needs pesticide registration (FIFRA Section 24c) for broadcast application of diphacinone $(0.005 \%$ in a grain-based pellet) for the control of rodents and wild pigs in Hawaii, its hazard to various species of birds was evaluated by both deterministic [37] and probabilistic [38] risk assessments. Using the greatest quantity of diphacinone found in a pig liver $(3.07 \mathrm{mg} / \mathrm{kg})$ and the available toxicity data for game birds (LD50 $>400 \mathrm{mg} / \mathrm{kg}$ for bobwhite), Eisemann and Swift [37] estimated the quantity of pig liver that would have to be scavenged by a Hawaiian hawk (Buteo solitarius; Federally listed as endangered) or a Hawaiian short-eared owl (Asio flammeus sandwichensis; State of Hawaii listed as endangered) to receive a median lethal dose would be $58.6 \mathrm{~kg}$ and $45.6 \mathrm{~kg}$, respectively. Because diphacinone is now known to be less toxic to game birds (LD50 2,014 mg/kg for bobwhite and LD50 3,158 for mallard) $[8,13]$, the quantity of pig liver that would have to be scavenged by these Hawaiian raptors would be even greater than originally estimated [37]. As a preliminary effort to refine this risk assessment, we used the acute toxicity data for American kestrels (LD50 $96.8 \mathrm{mg} / \mathrm{kg}$ ) from the present study. It is unlikely that the Hawaiian hawk or short-eared owl would frequently scavenge pigs, so we employed hepatic diphacinone residue data from field trials in Hawaii involving black rats (Rattus rattus; extreme value $=12 \mathrm{mg} / \mathrm{kg}$ ) that would more likely be consumed by the Hawaiian hawk and house mice (Mus musculus; extreme value $=3.8 \mathrm{mg} / \mathrm{kg}$ ) that would more likely be consumed by the short-eared owl (E.B. Spurr, U.S. Geological Survey, Pacific Island Ecosystem Research Center, Honolulu, HI, unpublished data).

Using the aforementioned diphacinone potency estimates for kestrels and rodent liver residue data in a deterministic approach [37], a $0.45-\mathrm{kg}$ Hawaiian hawk would have to consume $3.63 \mathrm{~kg}$ of liver from black rats and a $0.35-\mathrm{kg}$ short-eared owl would have to consume $8.92 \mathrm{~kg}$ of liver from house mice in order to ingest an acute median lethal dose in a 24-h period (Supplemental Data, Table S1). If sublethal effects in kestrels were considered (e.g., $50 \mathrm{mg} / \mathrm{kg}$ prolonged PT and RVVT, and $35.1 \mathrm{mg} / \mathrm{kg}$ produced microscopic hemorrhages), the amount of rodent liver consumed within a 24 -h period would be even lower, $1.32 \mathrm{~kg}$ for the hawk and $3.24 \mathrm{~kg}$ for the short-eared owl. These quantities of liver are far greater than the weight of both the Hawaiian hawk and short-eared owl, so the risk associated with a single-day exposure to diphacinone would be low. However, applying the kestrel dose-response curve for lethality and the rodent liver residue data in the probabilistic-based 1-d exposure model described by Johnston et al. [38], 50\% of male Hawaiian hawks would have a $1 \%$ probability of mortality if they consumed $0.0035 \mathrm{~kg}$ of liver from diphacinone-poisoned rats (Supplemental Data, Fig. S2). Likewise, $50 \%$ of the male Hawaiian short-eared owls would have a $1 \%$ probability of mortality if they consumed $0.0044 \mathrm{~kg}$ of mouse liver (Supplemental Data, Fig. S3). Because the dose-response curve does not permit an estimate of zero probability of lethality, the LD01 
was used as a surrogate metric for the no-effect level. For most wildlife populations, toxicant exposures associated with the LD01 would likely have little impact on population viability, although for endangered species this approach may be valid, insofar as regulations (e.g., Endangered Species Act) do not permit adverse impacts on such species. If the objective of natural resource managers is to ensure the viability of a particular wildlife species, the relative harm of rodenticides should be compared with the estimated rodent-induced population effects in the absence of such control.

Given the data for the lowest lethal dose (LLD) for repeated dietary exposures in mallards ( $L L D=0.6 \mathrm{mg} / \mathrm{kg} / \mathrm{d})$ [37] $(\mathrm{R}$. Long, Wildlife International, Easton, MD, USA, unpublished data) and the liver residue data from black rats and house mice, adverse effects could occur if consumption by the hawk exceeded $0.022 \mathrm{~kg}$ of rat liver/d and if consumption by the short-eared owl exceeded $0.055 \mathrm{~kg}$ of mouse liver/d, suggesting that repeated exposure would constitute a moderate risk to these species (Supplemental Data, Table S1). Furthermore, prolonged PT in 5- and 10-d feeding trials in golden eagles [18,37] occurred following ingestion of $0.11 \mathrm{mg}$ diphacinone $/ \mathrm{kg} / \mathrm{d}$, suggesting that the lowest observed effect level for the hawk and short-eared owl could be $0.004 \mathrm{~kg}$ of rodent liver $/ \mathrm{d}$ and $0.010 \mathrm{~kg}$ of rodent liver/d, respectively. Under this scenario, the quantities of liver are $<5 \%$ of the body weight of these raptors (viz. $4 \mathrm{~g}$ is $0.9 \%$ of hawk body weight and $10 \mathrm{~g}$ is $2.9 \%$ of owl body weight), so the Hawaiian hawk and short-eared owl would be at substantial risk of sublethal exposure. In view of the paucity of threshold effects data following repeated daily exposure of raptors to diphacinone, additional feeding trials in kestrels and owls are warranted to characterize better the uptake, tissue half-life, PT and RVVT responses, other potential adverse effects, and overall risk to birds of prey.

\section{CONCLUSIONS}

Diphacinone was found to be considerably more toxic to American kestrels than previously reported in traditionally used avian wildlife test species. Sublethal effects on blood clotting were detected at a dose of $50 \mathrm{mg} / \mathrm{kg}$, and histological evidence of hemorrhage was observed at $35.1 \mathrm{mg} / \mathrm{kg}$. Measurement of diphacinone residues in liver suggest that its half-life may be shorter than that reported for rats and pigs. Recent restrictions on the use of some second-generation anticoagulant rodenticides (http://www.epa.gov/pesticides/reregistration/rodenticides/finalriskdecision.htm) may result in increased diphacinone application. In conjunction with its implication in some mortality events in raptors [1,9], and the paucity of threshold effects data following repeated daily exposure for birds of prey, additional feeding trials with diphacinone and other more toxic anticoagulant rodenticides (e.g., brodifiacoum) in captive American kestrels and Eastern screech-owls are warranted to characterize better the risk of secondary poisoning.

\section{SUPPLEMENTAL DATA}

Table S1. Acute and sublethal dietary risk to birds from secondary poisoning by consumption of contaminated rodents. (36 KB PDF)

Fig. S1. Effect of diluting citrated kestrel plasma with phosphate buffer $(100,60,40,20$, and $15 \%$ plasma) on prothrombin time $\left(Y=9,605+16,289 \mathrm{e}^{-0.321 \text { (\% plasma) }} ; R^{2}=0.99\right)$.

Fig. S2. Probability mortality curve (LD01) of Hawaiian hawk consuming diphacinone-poisoned black rats.
Fig. S3. Probability mortality curve (LD01) of diphacinone in Hawaiian short-eared owl consuming poisoned house mice. (167 KB PDF)

Acknowledgement - The authors thank Wayne C. Bauer and Mary E. Maxey for animal care; Joann Beaver, Nimish B. Vyas, and Gary H. Heinz for suggestions related to dosing of kestrels; J. Christian Franson and Lesanna L. Lahner for help with preliminary studies; Marjory B. Brooks for guidance on the development of clotting assays; and Rebecca S. Lazarus for assistance with some statistical analyses. This work was supported by the U.S Department of Agriculture, the U.S. Geological Survey, and a grant from the California Department of Food and Agriculture Vertebrate Pest Control Research Advisory Committee (agreement 07-0832). Any use of trade, product, or firm names is for descriptive purposes only and does not imply endorsement by the U.S. government.

\section{REFERENCES}

1. Stone WB, Okoniewski JC, Stedelin JR. 2003. Anticoagulant rodenticides and raptors: recent findings from New York, 1998-2001. Bull Environ Contam Toxicol 70:34-40.

2. Lambert O, Pouliquen H, Larhantec M, Thorin C, L'Hostis M. 2007. Exposure of raptors and waterbirds to anticoagulant rodenticides (difenacoum, bromadiolone, coumatetralyl, coumafen, brodifacoum): Epidemiological survey in Loire Atlantique (France). Bull Environ Contam Toxicol 79:91-94.

3. Walker LA, Turk A, Long SM, Wienburg CL, Best J, Shore RF. 2008 Second generation anticoagulant rodenticides in tawny owls (Strix aluco) from Great Britain. Sci Total Environ 393:93-98.

4. Albert CA, Wilson LK, Mineau P, Trudeau S, Elliott JE. 2009. Anticoagulant rodenticides in three owl species from western Canada, 1988-2003. Arch Environ Contam Toxicol 58:451-459.

5. Eason CT, Spurr EB. 1995. Review of the toxicity and impacts of brodifacoum to non-target wildlife in New Zealand. NZ J Zool 22: 371-379.

6. Eason CT, Murphy EC, Wright GRG, Spurr EB. 2002. Assessment of risks of brodifacoum to non-target birds and mammals in New Zealand. Ecotoxicology 11:35-48.

7. Howald GR, Mineau P, Elliott JE, Cheng KM. 1999. Brodifacoum poisoning of avian scavengers during rat control on a seabird colony. Ecotoxicology 8:413-447.

8. Erickson W, Urban D. 2004. Potential risks of nine rodenticides to birds and nontarget mammals: A comparative approach. U.S. EPA P. 2004. 27 A. Office of Prevention, Pesticides and Toxic Substances, U.S Environmental Protection Agency, Washington, DC.

9. Stone WB, Okoniewski JC, Stedelin JR. 1999. Poisoning of wildlife with anticoagulant rodenticides in New York. $J$ Wildl Dis 35:187-193.

10. Bardo L, Bird DM. 2009. The use of captive American kestrels (Falco sparverius) as wildlife models: A review. J Raptor Res 43:345-364.

11. Porter RD, Wiemeyer SN. 1970. Propagation of American kestrels. $J$ Wildl Manag 34:594-604.

12. Luna LG. 1968. Manual of Histological Staining Methods of the Armed Forces Institute of Pathology, 3rd ed. McGraw Hill, New York, NY, USA.

13. Rattner BA, Horak KE, Warner SE, Johnston JJ. 2010. Acute toxicity of diphacinone in Northern bobwhite: Effects on survival and blood clotting. Ecotoxicol Environ Saf 73:1159-1164.

14. Griminger P, Shum YS, Budowski P. 1970. Effect of dietary vitamin K on avian brain thromboplastic activity. Poult Sci 49:1681-1686.

15. Doerr JA, Wyatt RD, Hamilton PB. 1975. Investigation and standardization of prothrombin times in chickens. Poult Sci 54:969-980.

16. Triplett DA, Harms CS. 1981. Procedures for the Coagulation Laboratory. Educational Products Division, American Society of Clinical Pathologists, Chicago, IL, USA.

17. Loomis TA. 1978. Essentials of Toxicology. Lea \& Febiger, London, UK.

18. Savarie PJ, Hayes DJ, McBride RT, Roberts JD. 1979. Efficacy and safety of diphacinone as a predacide. In Kenaga EE, ed, Avian and Mammalian Wildlife Toxicology. STP 693 American Society for Testing Materials, Philadelphia, PA, pp 69-79.

19. Mendenhall VM, Pank LF. 1980. Secondary poisoning of owls by anticoagulant rodenticides. Wildl Soc Bull 8:311-315.

20. Massey G, Valutis L, Marzluff J. 1997. Secondary poisoning effects of diphacinone on Hawaiian crows: a study using American crows as surrogates. Report to the U.S. Fish and Wildlife Service, Pacific Islands Office. Sustainable Ecosystems Institute, Meridian, ID. 
21. Watanabe KP, Saengtienchai A, Tanaka KD, Ikenaka Y, Ishizuka M 2010. Comparison of warfarin sensitivity between rat and birds species. Comp Biochem Physiol C 152:114-119.

22. Radvanyi A, Weaver P, Massari C, Bird D, Broughton E. 1988. Effects of chlorophacinone on captive kestrels. Bull Environ Contam Toxicol 41:441-448.

23. Newton I, Wyllie I, Freestone P. 1990. Rodenticides in British barn owls. Environ Pollut 68:101-117.

24. DuVall MD, Murphy MJ, Ray AC, Reagor JC. 1989. Case studies on second-generation anticoagulant rodenticide toxicities in nontarget species. J Vet Diagn Invest 1:66-68.

25. Fisher P, O'Connor C, Wright G, Eason CT. 2003. Persistence of four anticoagulant rodenticides in the livers of laboratory rats. Series 139 . Department of Conservation Research and Development, Wellington, New Zealand.

26. Fisher P. 2006. Persistence of residual diphacinone concentrations in pig tissue following sublethal exposure. Series 249. Department of Conservation Research and Development, Wellington, New Zealand.

27. Mount ME, Feldman BF. 1983. Mechanism of diphacinone rodenticide toxicosis in the dog and its therapeutic implications. Am J Vet Res 44:2009-2017.

28. Powers LV. 2000. Avian hemostasis. In Fudge AM, ed, Laboratory Medicine: Avian and Exotic Pets. W.B. Saunders, Philadelphia, PA, USA, pp 35-45.

29. Spinler SA, Nutescu EA, Smythe MA, Wittkowsky AK. 2005. Anticoagulation monitoring, part 1: Warfarin and parenteral direct thrombin inhibitors. Ann Pharmacother 39:1049-1055.

30. Shlosberg A, Booth L. 2006. Veterinary and clinical treatment of vertebrate pesticide poisoning-A technical review. Landcare Research, Lincoln, New Zealand.
31. Lee M, Morfini M, Negrier C, Chamouard C. 2006. The pharmacokinetics of coagulation factors. Haemophilia 12:1-7.

32. Rattner BA, Horak KE, Warner SE, Day DD, Johnston JJ. 2011 Comparative toxicity of diphacinone to northern bobwhite (Colinus virginianus) and American kestrels (Falco sparverius). Proceedings, 24th Vertebrate Pest Conference, Sacramento, CA, USA, February 22 25, 2010, pp 145-152.

33. Veltmann JR, Ross E Jr, Olbrich SE. 1981. The physiological effects of feeding warfarin to poultry. Poult Sci 60:2603-2611.

34. Martin GR, Kirkpatrick WE, King DR, Robertson ID, Hood PJ, Sutherland JR. 1994. Assessment of the potential toxicity of an anticoagulant, pindone (2-pivalyl-1,3-indandione), to some Australian birds. Wildl Res 21:85-93.

35. Massey JG, Valutis L, Marzluff J, Powers LV. 1997. The anticoagulant diphacinone's effect on crow prothrombin time. Proceedings, Annual Conference of the Association of Avian Veterinarians, Reno, NV, USA, September 9-13, pp 97-98.

36. Bailey C, Fisher P, Eason CT. 2005. Assessing anticoagulation resistance in rats and coagulation effects in birds using small-volume blood samples. Science for Conservation 249. New Zealand Department of Conservation, Wellington, New Zealand.

37. Eisemann JD, Swift CE. 2006. Ecological and human health hazards from broadcast application of $0.005 \%$ diphacinone rodenticide baits in native Hawaiian ecosystems. Proceedings, $22^{\text {nd }}$ Vertebrate Pest Conference, Berkeley, CA, USA, March 6-9, pp 413-433.

38. Johnston JJ, Pitt WC, Sugihara RT, Eisemann JD, Primus TM, Holmes MJ, Crocker J, Hart A. 2005. Probabilistic risk assessment for snails, slugs, and endangered honeycreepers in diphacinone rodenticide baited areas on Hawaii, USA. Environ Toxicol Chem 24: 1557-1567. 
Table S1. Acute and sublethal dietary risk to birds from secondary poisoning by consumption of diphacinone contaminated rodents ${ }^{\mathrm{a}}$

\begin{tabular}{lcccccc}
\hline Species & $\begin{array}{c}\text { Weight } \\
(\mathrm{kg})\end{array}$ & $\begin{array}{c}\text { LD50 } \\
(\mathrm{mg} / \mathrm{kg})^{\mathrm{b}}\end{array}$ & $\begin{array}{c}\text { LD50 secondary exposure } \\
(\mathrm{g} \text { liver })^{\mathrm{c}}\end{array}$ & $\begin{array}{c}\text { Lowest lethal dose (LLD) } \\
(\mathrm{mg} / \mathrm{kg} / \mathrm{day})^{\mathrm{d}}\end{array}$ & $\begin{array}{c}\text { LLD secondary exposure } \\
(\mathrm{g} \text { liver })^{\mathrm{c}}\end{array}$ & $\begin{array}{c}\text { LOEL sublethal toxicity } \\
(\mathrm{mg} / \mathrm{kg} / \mathrm{day})^{\mathrm{e}}\end{array}$ \\
\hline Hawaiian hawk & 0.45 & $96.8 \mathrm{mg} / \mathrm{kg}$ & 3,630 & 0.6 & 22.5 & 0.11 \\
Hawaiian short-eared owl & 0.35 & $96.8 \mathrm{mg} / \mathrm{kg}$ & 8,916 & 0.6 & 55.3 & 0.11 \\
\hline
\end{tabular}

${ }^{a}$ Calculated values are the quantities of food required to be ingested to equal the lowest reported avian lethal dose, $50 \%$ (LD50), lowest lethal dose (LLD) and lowest-observed-effect level (LOEL).

${ }^{\mathrm{b}}$ Based on median lethal dose for American kestrel (present study).

${ }^{\mathrm{c}}$ Based on greatest diphacinone residue found in black rat liver $(12 \mathrm{mg} / \mathrm{kg})$ that could be consumed by an Hawaiian hawk in a $24 \mathrm{~h}$ period, and greatest residue found in house mouse liver (3.8 mg/kg) that could be consumed by an Hawaiian short-eared owl in a 24 h period (unpublished data, Spurr EB, U.S. Geological Survey, Pacific Island Ecosystem Research Center, Honolulu, HI, USA).

${ }^{\mathrm{d}}$ Based on lowest lethal dose in mallard acute dietary toxicity study (unpublished data, Long R, Wildlife International, Easton MD, USA).

${ }^{e}$ Based on lowest observed effect level for prolonged blood clotting time in golden eagles [18]. 


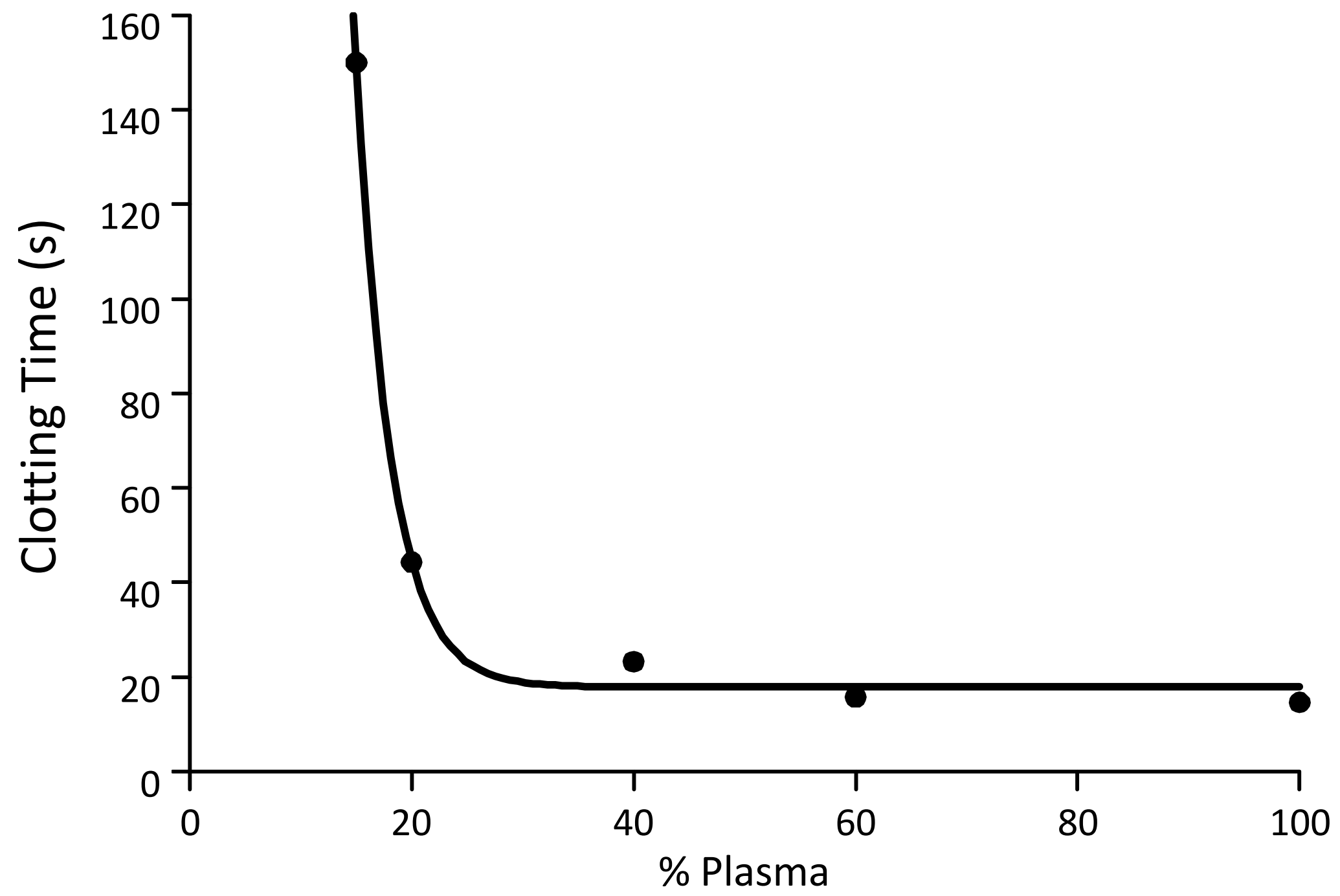


Male Hawaiian Hawk

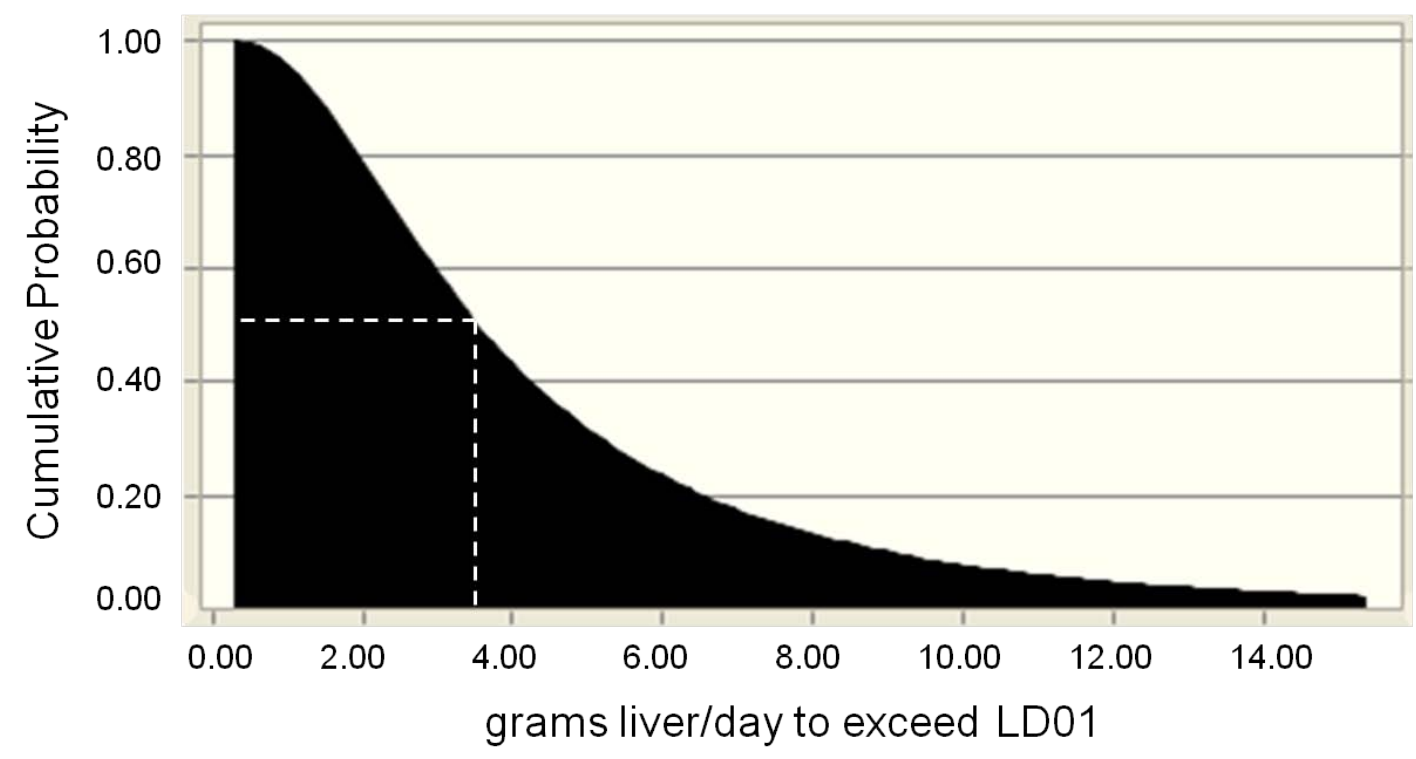


Male Hawaiian Short-Eared Owl

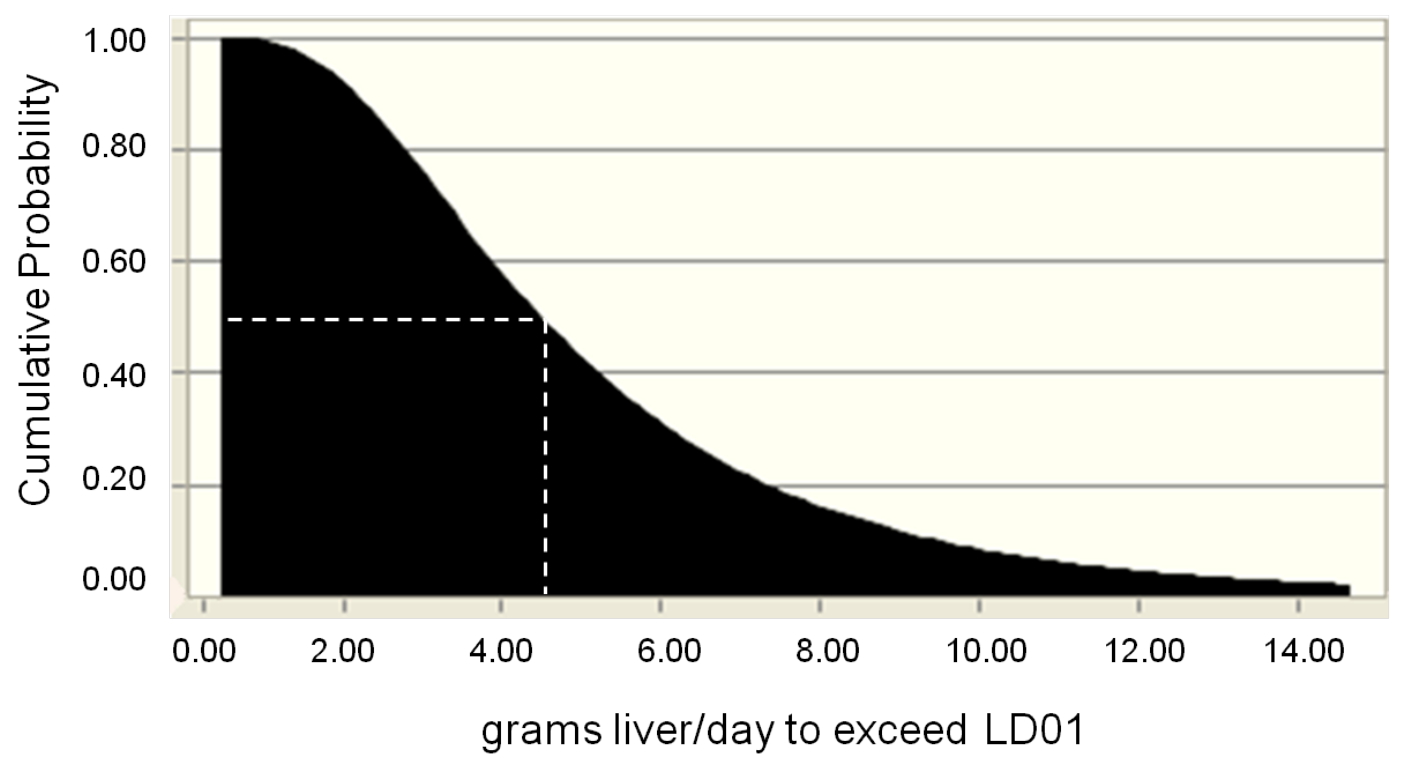

